\title{
The Significance of Apatite Inclusions in Soil Phosphorus Studies ${ }^{1}$
}

\author{
J. K. Syers, J. D. H. Williams, A. S. Campbell, and T. W. Walker ${ }^{2}$
}

\begin{abstract}
Apatite inclusions have been identified in several primary minerals, and their abundance and morphology have been described. A comparison of several methods used for the determination of total $P$ in soils showed that $\mathrm{Na}_{2} \mathrm{CO}_{3}$ fusion is the most reliable method for samples which contain apatite inclusions and that the effectiveness of extraction was usually in the order: $\mathrm{Na}_{2} \mathrm{CO}_{3}$ fusion $>\mathrm{HF}$ digestion $>\mathrm{HClO}_{4}$ digestion $>\mathrm{N} \mathrm{H}_{2} \mathrm{SO}_{4}$ extraction following ignition. Included apatite was identified using a petrological microscope in residues after digestion with $60 \% \mathrm{HClO}_{4}$. This form was also extracted much more slowly by $0.5 N \mathrm{HCl}$ than was nonincluded apatite. Included apatite resistant to attack by $1 N \mathrm{HCl}$ was determined as "residual inorganic $\mathbf{P}^{\prime \prime}$ in fractionation studies on weakly weathered materials, and the infuence of fineness of grinding on the ratio of "acid-extractable Ca-P" to residual inorganic P indicated the likely dimensions of the inclusions in different minerals.
\end{abstract}

Additional Key Words for Indexing: abundance, morphology

$\mathbf{T}$

THE PHENOMENON of included apatite is well established in petrology. (There is confusion in the literature regarding the use of the terms "included" and "occluded." In this paper the term "included" refers to "a mineral species present within the matrix of another mineral species.") Apatite appears to be one of the more common minerals which occur as inclusions within the major mineral phases in igneous rocks.
In particular, apatite inclusions are relatively abundant in xenoliths (Nockolds, 1933). The literature indicates that included apatite may be found in a wide range of minerals, e.g., in quartz (Fry, 1913; Piummer, 1915; Krumbein and Pettijohn, 1938; Williams, Turner and Gilbert, 1954); in volcanic glass (Peck, 1965); in iron-titanium oxides (Clarke, 1916; Wright and Lovering, 1965); in plagioclase feldspars (Peck, 1965; Ewart, 1965); in biotite (Hutton, 1936; Wodzicki, 1959); in muscovite and chlorite (Wodzicki, 1959); and in hypersthene and augite (Ewart, 1963).

With the exception of the work of Fry (1913), who showed that apatite "enclosed in quartz" was not attacked by prolonged digestion with $\mathrm{HCl}$, and Dean (1937), who concluded that the insoluble forms of phosphorus (not removed by acid or alkaline extraction) in a residual titaniferous soil were of primary origin and were probably held as an inclusion within the primary minerals, little consideration has been given in soil phosphorus studies to the positional mode of occurrence

'Contribution from the Dep. of Soil Sci. Lincoln College, Univ. of Canterbury, New Zealand. Supported in part by scholarships to the first two authors from the Commonwealth Scholarship and Fellowship Plan. Presented before Div. S-2, Soil Sci. Soc. Amer., Nov. 5-10, 1967, Washington, D.C. Received May 29, 1967. Approved July 19, 1967.

${ }^{2}$ Formerly Research Fellow, now Project Associate, Univ. of Wisconsin; formerly Graduate Student, now Scientific Officer, Rothamsted Exp. Sta., Harpenden, Herts., England; Lecturer; and Professor of Soil Science, respectively. 
of apatite, i.e., whether present as separate grains of apatite or as inclusions within other minerals.

In a study of the amounts and distribution of the forms of inorganic phosphorus in a New Zealand chronosequence of soils developed on windblown sand, it was found that included apatite was the dominant form of phosphorus in the parent material and in many of the younger soils. The purpose of this paper is to examine some aspects of the significance of apatite inclusions in soil phosphorus studies.

\section{MATERIALS}

Four beach sands (representing the stage of time-zero in a chrononsequence of sandy soils) derived from a mixture of graywacke and rocks of the central North Island volcanic suites were collected from the West Wellington coast, New Zealand. The surface and lowest horizons of the oidest soil in the chronosequence, Koputaroa sandy loam (Cowie, 1963), were also used. Hypersthene and plagioclase feldspar from a rhyolitic pumice ash, Taupo bed No. 2 (Ewart, 1963), were also analyzed along with a weathered feldspar concentrate from beach sand 1. A sample of unweathered graywacke and mica-schist from the Franz Josef Chronosequence, New Zealand (P. R. Stevens, 1963. M. S. Thesis. Lincoln College, University of Canterbury), was used as an example of a parent material which did not contain detectable amounts of included apatite.

The authors are indebted to Drs. K. R. Gill and A. Ewart, New Zealand Geological Survey, for assistance with the petrological work and for providing the hypersthene and plagioclase samples.

\section{METHODS}

Hypersthene and plagioclase were isolated from the rhyolitic pumice ash by passing lightly-crushed material through the Frantz isodynamic separator. Plagioclase was purified by centrifuging in bromoform-acetone mixtures, and hypersthene, by repeated centrifuging in mixtures of Clerici solution and distilled water.

The weathered feldspar concentrate was obtained by centrifuging in bromoform-acetone mixtures. Grain mounts of all samples were prepared using Canada balsam. The following size fractions of the materials were used, unground, $<250 \mu,<150 \mu$, $<75 \mu$, and these were obtained by crushing and screening in a dry state. Micronized samples of hypersthene and plagioclase were obtained by grinding in a Tema crusher for $3 \mathrm{~min}$ and mean particle size was determined by measuring under a microscope the diameter of 200 particles of a subsample, mounted on a glass slide.

Total $\mathrm{P}$ in the samples was determined using extraction with $1 \mathrm{~N} \mathrm{H}_{2} \mathrm{SO}_{4}$ following ignition (Walker and Adams, 1958); digestion with $60 \% \mathrm{HClO}_{4}$ (Jackson, 1958); digestion with $\mathrm{HF}$ following pretreatment with $\mathrm{HNO}_{3}$ and ignition (Metson, 1956, as modified by Williams ${ }^{3}$ ); and fusion with $\mathrm{Na}_{2} \mathrm{CO}_{3}$ (Muir, 1952) except that $9 \mathrm{~N} \mathrm{H}_{2} \mathrm{SO}_{4}$ was used for removal of the melt (Jackson, 1958). In all cases phosphorus was determined colorimetrically by the method of Fogg and Wilkinson (1958).

To compare the release of phosphorus from two samples, one of which contained included apatite and the other nonincluded apatite, $0.5 \mathrm{~g}$ of $<150 \mu$ material, previously treated with $0.5 \mathrm{M}$ $\mathrm{NH}_{4} \mathrm{~F}, 0.1 \mathrm{~N} \mathrm{NaOH}$, and dithionite-citrate-bicarbonate, was extracted at $25 \mathrm{C}$ with $0.5 \mathrm{~N} \mathrm{HCl}$ for increasing periods of time up to 8 hours. After centrifuging, phosphorus was determined colorimetrically by the method of Dickman and Bray (1940). A fractionation procedure was used to determine the forms of inorganic phosphorus in the samples (Williams et al., 1967).

${ }^{3}$ Williams, J. D. H. Forms of soil phosphate in some genetically-related New Zealand soils. Ph.D. Thesis, 1965, Lincoln College, University of Canterbury, New Zealand. To eliminate fluoride, the three evaporations with $\mathrm{HNO}_{3}$ are replaced by digestion with $10 \mathrm{~N} \mathrm{H}_{2} \mathrm{SO}_{4}$ until fuming just starts.

\section{RESULTS AND DISCUSSION}

\section{Distribution and Morphology of Apatite Inclusions}

Euhedral needles and prisms of apatite were present as inclusions in several of the volcanic-derived minerals in beach sands 1-4. (The diagnostic properties used in the microscopic identification of apatite inclusions in these samples were prismatic or acicular habit, absence of color, moderately high relief, and weak birefringence.) Also there was no evidence from optical mineralogy of the existence of separate grains of apatite in the samples. Similar findings applied to samples from the Koputaroa sandy loam. Apatite inclusions were abundant in hypersthene, common in augite and plagioclase, occasional in hornblende and biotite, and rare in volcanic glass and quartz. In addition to apatite inclusions, magnetite and volcanic glass inclusions were very common in beach sands $1-4$, the former more abundant than apatite. The euhedral needles and prisms of apatite were apparently randomly distributed within the host mineral. Average dimensions of the inclusions were $50 \mu$ length and $5 \mu$ thickness, although length varied from 10 to $80 \mu$ and thickness from 1 to $10 \mu$.

Included apatite was particularly abundant in hypersthene (Fig. 1) and common in plagioclase separated from rhyolitic pumice ash. Ewart (1963) has discussed the distribution of inclusions in rhyolitic pumice ash of the Taupo area and has identified apatite in several minerals. In hypersthene used in the present study the inclusions were frequently needle-like (acicular) and larger, up to $200 \mu$ in length, although average thickness was approximately $5 \mu$. Included apatite was identified in magnetite and ilmenite inclusions in hypersthene; inclusions of apatite in magnetite and ilmenite have been reported by Clarke (1916) and Wright and Lovering (1965). (The former has been confirmed by electron-microprobe analysis kindly done by Dr. E. H. Tyner, University of Illinois, Urbana.)

\section{Total P Determination}

The results in Table 1 show that of the four methods investigated, $\mathrm{Na}_{2} \mathrm{CO}_{3}$ fusion gave the highest values for all the samples. Lower values were given by extraction with $1 N$ $\mathrm{H}_{2} \mathrm{SO}_{4}$ following ignition and by digestion with $60 \% \mathrm{HClO}_{4}$, indicating that these two procedures are unsuitable for the determination of total $\mathrm{P}$ in materials which contain included apatite. Although widely used, the $\mathrm{HClO}_{4}$ digestion procedure

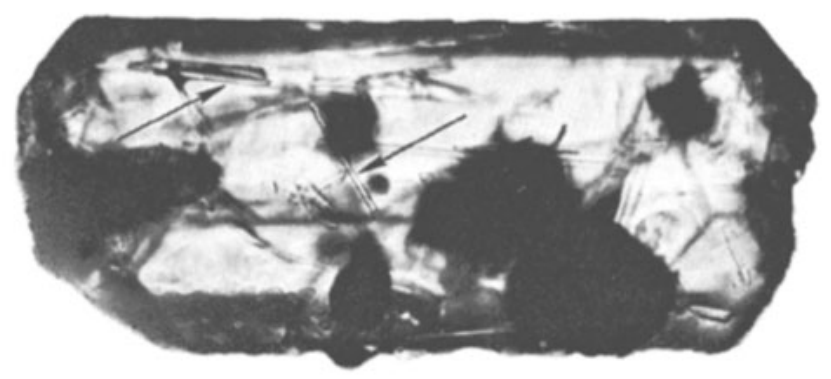

$100 \mu$

Fig. 1-Acicular apatite inclusions and larger, black, magnetite inclusions in hypersthene. 
Table 1 -Determination of total $P$ in materials $\left(<150_{\mu}\right)$ which contain included apatite using $N \mathrm{H}_{2} \mathrm{SO}_{4}$ following ignition, digestion with $60 \% \mathrm{HClO}_{4}$, digestion with $\mathrm{HF}$, and $\mathrm{Na}_{2} \mathrm{CO}_{3}$ fusion

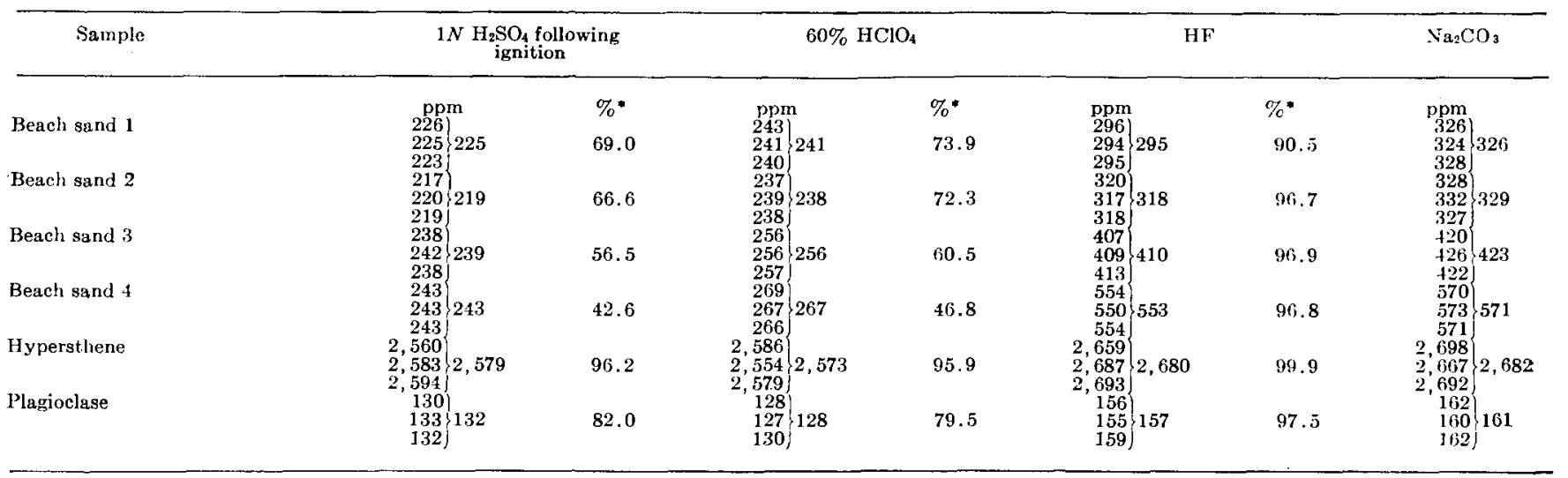

- P extracted expressed as a percentage of $\mathrm{Na}_{2} \mathrm{CO}_{3}$ fusion value.

Table 2-Effect of fineness of grinding on the determination of total $P$ in two samples which contain included apatite using $\mathrm{N} \mathrm{H}_{2} \mathrm{SO}_{4}$ following ignition, digestion with $60 \% \mathrm{HClO}_{4}$, and digestion with $\mathrm{HF}$

\begin{tabular}{lcccc}
\hline Sample & $\begin{array}{c}\text { Fineness of } \\
\text { grinding }\end{array}$ & $\begin{array}{l}1 \mathrm{~N} \mathrm{H}_{2} \mathrm{SO}_{4} \\
\text { following } \\
\text { ignition }\end{array}$ & $60 \% \mathrm{HClO}$ & $11 \mathrm{~F}$ \\
\hline & & - & & \\
Beach sand 2 & unground & 204 & 232 & 310 \\
Beach sand 2 & $<250 \mu$ & 213 & 234 & 312 \\
Beach sand 2 & $<150 \mu$ & 219 & 238 & 318 \\
Beach sand 2 & $<75 \mu$ & 222 & 247 & 324 \\
Beach sand 3 & unground & 221 & 241 & 361 \\
Beach sand 3 & $<250 \mu$ & 228 & 248 & 382 \\
Beach sand 3 & $<150 \mu$ & 239 & 256 & 410 \\
Beach sand 3 & $<75 \mu$ & 243 & 267 & 414 \\
\hline
\end{tabular}

frequently gives lower results for total $\mathrm{P}$ in soils than $\mathrm{Na}_{2} \mathrm{CO}_{3}$ fusion (Muir, 1952; Jackson, 1958; Mattingley, 1965; Sherrell and Saunders, 1966). Using $\mathrm{HClO}_{4}$ digestion, the recovery of $\mathrm{P}$ added as $\mathrm{KH}_{2} \mathrm{PO}_{4}$ was $99.8 \%$. Incomplete extraction of phosphorus from the samples is apparently responsible for the low results. Apatite inclusions were identified in hypersthene, augite, and quartz in the residues of beach sands 1-4 after digestion with $60 \% \mathrm{HClO}_{4}$. Low values may therefore be ascribed to the partial resistance to attack of these minerals which contain apatite inclusions.

In the case of hypersthene and plagioclase, but not with the beach sands, the $1 \mathrm{~N} \mathrm{H}_{2} \mathrm{SO}_{4}$ procedure extracted more phosphorus than did digestion with $60 \% \mathrm{HClO}_{4}$. This was perhaps related to the considerably longer extraction time with the former (16 hours) and the opening of cleavage and fracture planes in the minerals during the ignition treatraent.

One evaporation with $\mathrm{HF}$ extracted more phosphorus from all samples than did digestion with $60 \% \mathrm{HClO}_{4}$, but these values were, with the exception of hypersthene, always lower than those obtained with $\mathrm{Na}_{2} \mathrm{CO}_{3}$ fusion. When the means of the triplicate results for total $\mathrm{P}$ obtained by $\mathrm{HF}$ digestion and $\mathrm{Na}_{2} \mathrm{CO}_{3}$ fusion in each of samples 1-4 were paired and compared statistically, it was found that the difference was significant at the $0.01 \%$ level. Quartz has been identified in the residues of beach sands $1-4$ following one evaporation with $\mathrm{HF}$, and it is tempting to suggest that the small amount of phosphorus not extracted by $\mathrm{HF}$ is present as apatite inclusions within undigested quartz. This would imply that when apatite inclusions are present in samples undergoing analysis for total $P$, it is necessary to give at least two evaporations with $\mathrm{HF}$. These findings suggest that $\mathrm{Na}_{2} \mathrm{CO}_{3}$ fusion is the most reliable method for the determination of total $\mathrm{P}$ in materials which contain apatite inclusions.

The amount of phosphorus extracted from beach sand samples 2 and 3 by $1 \mathrm{~N} \mathrm{H}_{2} \mathrm{SO}_{4}$ after ignition, $60 \% \mathrm{HClO}_{4}$ digestion, and $\mathrm{HF}$ digestion, increased slightly with increasing fineness of grinding (Table 2), although grinding to $<75 \mu$ did not produce any marked increase in the amount of phosphorus extracted. This is probably related to the relatively small size of many of the apatite inclusions. The values obtained for total $\mathrm{P}$ in beach sands 2 and 3 using $\mathrm{HF}$ digestion and $<75 \mu$ material approached the results obtained by $\mathrm{Na}_{2} \mathrm{CO}_{3}$ fusion (Table 1).

\section{Extraction with $0.5 \mathrm{~N} \mathrm{HCl}$}

The results obtained for the release of inorganic phosphorus by $0.5 N \mathrm{HCl}$ extraction $(25 \mathrm{C}$ ) from $<150 \mu$ samples of beach sand 3, which contains included apatite, and from unweathered graywacke and mica-schist from the Franz Josef Chronosequence are shown in Fig. 2. Phosphorus fractionation

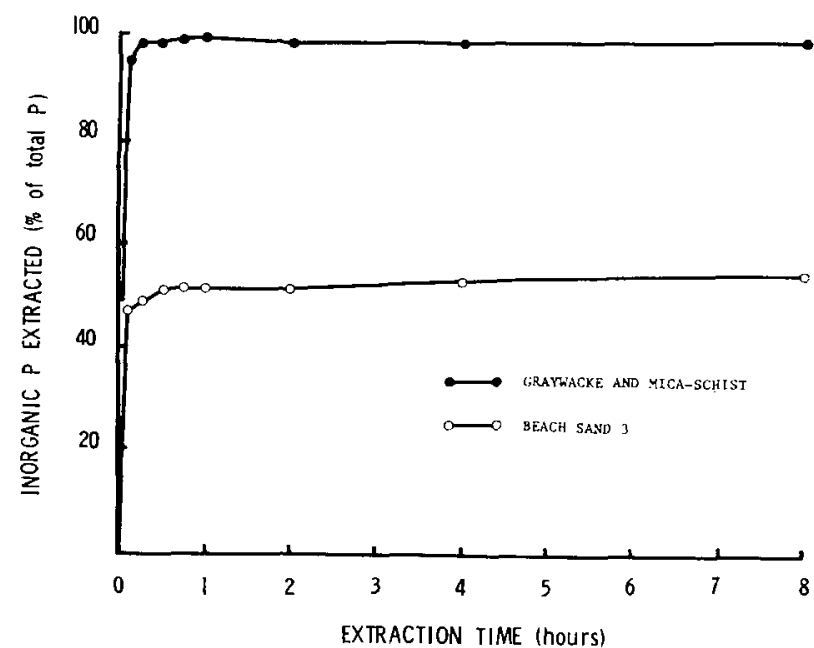

Fig. 2-Effect of time of extraction on the release of inorganic $\mathrm{P}$ by $0.5 N \mathrm{HCl}$ from beach sand 3 and unweathered graywacke and mica-schist $($ both $<150 \mu$ ). Extractions done at $25 \mathrm{C}$. 
results indicate that both these samples contain apatite and $<15 \mathrm{ppm}$ of other forms of phosphorus, which is largely organic phosphorus. (Samples treated with $0.5 M \mathrm{NH}_{4} \mathrm{~F}$, $0.1 N \mathrm{NaOH}$, and dithionite-citrate-bicarbonate prior to extraction with $0.5 N \mathrm{HCl}$.) In the case of unweathered graywacke and mica-schist, $98.0 \%$ of total $\mathrm{P}$ in the sample was extracted after 15 minutes, whereas with beach sand 3 , only $48.8 \%$ of total $P$ was extracted. With increasing time of extraction up to 8 hours, the release of inorganic phosphorus from the unweathered graywacke and mica-schist sample remained constant, but with beach sand 3 increased slightly to $53.1 \%$ at 8 hours. The lower value for percentage release of inorganic $P$ from beach sand 3 may be ascribed to the presence of apatite inclusions within primary minerals. It appears that part of the included apatite in beach sand 3 can be released by acid extraction because of both the effect of grinding and, in the case of certain minerals, because of planes of weakness, e.g., cleavage in the host mineral.

\section{Inorganic Phosphorus Fractionation}

Results for a fractionation of inorganic phosphorus are shown in Table 3. Most, but not all, of the acid-extractable $\mathrm{Ca}-\mathrm{P}$ was brought out by a 1 -hour extraction with $0.5 \mathrm{~N} \mathrm{HCl}$ in the case of the beach sands and the sample of weathered feldspar. A small amount of inorganic phosphorus was extracted from these samples in the second $\mathrm{HCl}$ extraction using $1 N \mathrm{HCl}$ and a 4 -hour extraction period. The magnitude of the residual inorganic $P$ fraction was variable but high in beach sands 3 and 4 . High values for residual inorganic $\mathrm{P}$ are usually anticipated with moderately and strongly weathered soils where inorganic phosphorus may be randomly dispersed in the matrices of iron-oxide coatings and concretions (Bauwin and Tyner, 1957). Following the determination of acidextractable Ca-P, samples of the beach sands were examined using a petrological microscope, and apatite inclusions were identified in hypersthene, augite, and plagioclase. Because extraction with 0.5 and $1 N \mathrm{HCl}$ did not remove all the apatite from these samples, this fraction has been designated acid-extractable $\mathrm{Ca}-\mathrm{P}$ to avoid confusion in nomenclature (Williams et al., 1967). It was previously thought that the "residual or" inert" phosphate fraction in soils was largely "lattice P" (Kurtz, 1953). The present findings indicate that this fraction can consist of included apatite (not acid-extractable) in addition to secondary inorganic forms of phosphorus (Bauwin and Tyner, 1957; Chang and Jackson, 1957).

In the Koputaroa profile, acid-extractable $\mathrm{Ca}-\mathrm{P}$ and residual inorganic $\mathrm{P}$ increased with depth, whereas secondary forms of inorganic phosphorus such as $\mathrm{NH}_{4} \mathrm{~F}$-P etc. declined (Table 3): this is consistent with a primary origin for residual inorganic P. (cf. Dean, 1937). Had this fraction consisted of secondary inorganic phosphorus, a decrease in the magnitude down the profile would have been anticipated, due to the stronger weathering in surface horizons.

With the exception of a small amount of reductant-soluble $P$ in plagioclase, unground hypersthene and plagioclase did not contain any secondary inorganic phosphorus (Table 4). With increased fineness of grinding, however, there was usually an increase in the inorganic phosphorus extracted by $\mathrm{NH}_{4} \mathrm{Cl}$, $\mathrm{NH}_{4} \mathrm{~F}, \mathrm{NaOH}$, and dithionite-citrate-bicarbonate. These reagents are not generally considered to extract Ca-P. This will be discussed in a future publication. The proportion of acid-extractable $\mathrm{Ca}-\mathrm{P}$ to residual inorganic $\mathrm{P}$ was appreciably affected by degree of fineness of grinding. With increased fineness of grinding 2nd HCl-P declined markedly, and there

Table 3-Inorganic phosphorus fractionation results using $<250 \mu$ samples

\begin{tabular}{|c|c|c|c|c|c|c|c|c|c|c|c|}
\hline \multirow[b]{2}{*}{ Sample } & \multicolumn{10}{|c|}{ Inorganic phcsphorus fraction } & \multirow[b]{2}{*}{ Total P } \\
\hline & $\begin{array}{c}\text { Easily- } \\
\text { soluble } P\end{array}$ & $\mathrm{NH}_{4} \mathrm{~F}-\mathrm{P}$ & $\begin{array}{l}1 \mathrm{st} \\
\mathrm{NaOH}-\mathrm{P}\end{array}$ & $\begin{array}{c}\text { Reductant- } \\
\text { soluble P }\end{array}$ & $\begin{array}{l}\text { 2nd } \\
\mathrm{NaOH}-\mathrm{P}\end{array}$ & $\begin{array}{l}\text { lst } \\
\text { HCl-P }\end{array}$ & $\begin{array}{l}\text { 2nd } \\
\text { HCl-P }\end{array}$ & $\begin{array}{l}\text { Acid-extract- } \\
\text { able Ca-P* }\end{array}$ & $\begin{array}{c}\text { Residual } \\
\text { inorg. P }\end{array}$ & $\begin{array}{l}\text { Total } \\
\text { inorg. Pt }\end{array}$ & \\
\hline $\begin{array}{l}\text { Beach sand } 1 \\
\text { Beach sand } 2 \\
\text { Beach sand } 3 \\
\text { Beach annd } 4 \\
\text { Koputaroa } 3-13 \mathrm{~cm} \\
\text { Koputaroa } 89-100 \mathrm{~cm} \\
\text { Weathered feldspar from beach and } 1\end{array}$ & $\begin{array}{l}0 \\
0 \\
0 \\
0 \\
0 \\
0 \\
0\end{array}$ & $\begin{array}{r}8 \\
9 \\
17 \\
19 \\
88 \\
44 \\
12\end{array}$ & $\begin{array}{r}13 \\
8 \\
2 \\
3 \\
39 \\
16 \\
13\end{array}$ & $\begin{array}{l}28 \\
43 \\
57 \\
77 \\
44 \\
40 \\
26\end{array}$ & $\begin{array}{l}5 \\
8 \\
5 \\
6 \\
6 \\
8 \\
6\end{array}$ & $\begin{array}{r}p p m \\
178 \\
161 \\
167 \\
130 \\
0 \\
12 \\
273\end{array}$ & $\begin{array}{r}8 \\
7 \\
7 \\
6 \\
0 \\
0 \\
17\end{array}$ & $\begin{array}{r}186 \\
168 \\
174 \\
136 \\
0 \\
12 \\
290\end{array}$ & $\begin{array}{r}80 \\
83 \\
153 \\
290 \\
38 \\
76 \\
46\end{array}$ & $\begin{array}{l}320 \\
319 \\
408 \\
531 \\
215 \\
196 \\
393\end{array}$ & $\begin{array}{l}325 \\
329 \\
423 \\
571 \\
584 \\
211 \\
403\end{array}$ \\
\hline
\end{tabular}

- Acid-extractable Ca-P = 1st HCl-P + 2nd HCl-P.

+ Total inorg. $P=$ sum of inorganic $P$ fractions.

$\ddagger$ Total $\mathrm{P}$ by $\mathrm{Na}_{2} \mathrm{CO}_{3}$ fusion.

Table 4-Effect of grinding on inorganic phosphorus fractions in hypersthene and plagioclase

\begin{tabular}{|c|c|c|c|c|c|c|c|c|c|c|}
\hline \multirow{2}{*}{ Sample } & \multicolumn{10}{|c|}{ Inorganic phosphorus fraction } \\
\hline & $\begin{array}{l}\text { Easily- } \\
\text { soluble P }\end{array}$ & $\mathrm{NH}_{4} \mathrm{~F}-\mathrm{P}$ & $\begin{array}{c}1 \mathrm{st} \\
\mathrm{NaOH}-\mathrm{P}\end{array}$ & $\begin{array}{l}\text { Reductant- } \\
\text { soluble P }\end{array}$ & $\begin{array}{l}\text { 2nd } \\
\mathrm{NaOH}-\mathrm{P}\end{array}$ & $\begin{array}{l}\text { lst } \\
\text { HCI-P }\end{array}$ & $\begin{array}{l}\text { 2nd } \\
\text { HCl-P }\end{array}$ & $\begin{array}{c}\text { Acid- } \\
\text { extractable } \\
\text { Ca-P }\end{array}$ & $\begin{array}{l}\text { Regidugl } \\
\text { inorg. } \mathrm{P}\end{array}$ & $\begin{array}{l}\text { Total } \\
\text { inorg. P† }\end{array}$ \\
\hline $\begin{array}{l}\text { Hypersthene unground } \\
\text { Hypersthene < } 250 \mu \\
\text { Hypersthene micronized } \\
\text { Plagiociase unground } \\
\text { Plagioclase < } 250 \mu \\
\text { Plagioclase micronized } \$\end{array}$ & $\begin{array}{r}0 \\
19 \\
97 \\
0 \\
0 \\
0\end{array}$ & $\begin{array}{r}0 \\
3 \\
287 \\
0 \\
\text { I } \\
34\end{array}$ & $\begin{array}{r}0 \\
1 \\
436 \\
0 \\
1 \\
7\end{array}$ & $\begin{array}{r}0 \\
12 \\
453 \\
4 \\
9 \\
14\end{array}$ & $\begin{array}{r}0 \\
0 \\
42 \\
0 \\
0 \\
2\end{array}$ & $\begin{array}{r}1,890 \\
2,303 \\
1,278 \\
107 \\
117 \\
74\end{array}$ & $\begin{array}{r}394 \\
178 \\
65 \\
10 \\
2 \\
1\end{array}$ & $\begin{array}{r}2,284 \\
2,481 \\
1,343 \\
117 \\
119 \\
75\end{array}$ & $\begin{array}{r}361 \\
134 \\
32 \\
37 \\
31 \\
26\end{array}$ & $\begin{array}{r}2,645 \\
2,650 \\
2,690 \\
158 \\
161 \\
158\end{array}$ \\
\hline
\end{tabular}

- Acid-extractable Ca-P = 1st HCl-P + 2nd HCl-P.

+ Total inorg. $P=$ sum of inorganic $P$ fractions.

Mean particle size $=2.1 \mu \pm 1.2$.
Mean particle size $=1.9 \mu \pm 1.0$. 
was an accompanying decrease in the magnitude of the residual inorganic $\mathrm{P}$ fraction in hypersthene. The decline in residual inorganic $P$ with increased fineness of grinding was less pronounced in plagioclase and is perhaps due to the apatite inclusions being extremely minute in this sample.

\section{CONCLUSIONS}

Apatite is the most commonly occurring phosphorus-bearing mineral in soils and is usually the starting point for phosphorus transformations in unfertilized soils. As the presence of included apatite has important implications, a knowledge of the positional mode of occurrence of apatite is desirable in soil phosphorus studies.

The rate of release of phosphorus from minerals which contain included apatite will depend to a large extent on the ease of weathering of the host mineral, with the presence of inclusions possibly accelerating the weathering rate (Raeside, 1959). The presence of included apatite in quartz, magnetite, and ilmenite is particularly significant as these minerals are relatively resistant to weathering. Release of phosphorus from well-cleaved minerals, e.g., hypersthene and plagioclase, may be envisaged without any extensive disintegration of the host mineral. The fact that apatite can be present as inclusions in soil minerals instead of discrete grains may exert a considerable influence on the availability of phosphorus and on the rate and pattern of inorganic phosphorus transformations in soils.

\section{LITERATURE CITED}

1. Bauwin, G. R., and E. H. Tyner. 1957. The nature of reductant-soluble phosphorus in soils and soil concretions. Soil Sci. Soc. Amer. Proc. $21: 250-257$.

2. Chang, S. C., and M. L. Jackson. 1957. Fractionation of soil phosphorus. Soil. Sci. 84:133-144.

3. Clarke, F. W. 1916. Data of geochemistry. US Geol. Surv. Bull. 616.

4. Cowie, J. D. 1963. Dune-building phases in the Manawatu district, New Zealand. New Zeal. J. Geol. Geophys. 6:268280.

5. Dean, L. A. 1937. Distribution of the forms of soil phosphorus. Soil Sci. Soc. Amer. Proc. 2:223-227.

6. Dickman, S. R., and R. H. Bray. 1940. Colorimetric determination of phosphate. Ind. Eng. Chem. Anal. Ed. 12:665-668.

7. Ewart, A. 1963. Petrology and petrogenesis of the Quaternary pumice ash, in the Taupo area, New Zealand. J. Petrol. 4:392-431.

8. 1965. Mineralogy and petrogenesis of the
Whakamaru ignimbrite in the Maraetai area of the Taupo volcanic zone, New Zealand. New Zeal. J. Geol. Geophys. $8: 611-677$.

9. Fogg, D. N., and N. T. Wilkinson. 1958. The colorimetric determination of phosphorus. Analyst, 83:406-414.

10. Fry, W. H. 1913. The condition of soil phosphoric acid insoluble in hydrochloric acid. J. Ind. Eng. Chem. 5:665666.

11. Hutton, C. O. 1936. Igneous boulders from the Lake Wakatipu district. Trans, Proc. New Zeal. Inst, 66:27-34.

12. Jackson, M. L. 1958. Soil Chemical Analysis, PrenticeHall, Inc., Englewood Cliffs, N. J.

13. Krumbein, W. C., and F. J. Pettijohn. 1938. Manual of sedimentary petrography. Appleton-Century-Crofts, Inc., New York.

14. Kurtz, L. T. 1953. Inorganic phosphorus in acid and neutral soils. In W. H. Pierre and A. G. Norman (ed.) Soil and fertilizer phosphorus. Agronomy 4:59-88.

15. Mattingley, G.E.G. 1965. Determining total phosphorus in soils. Rep. Rothamst. Exp. Sta. for 1964, 71-72.

16. Metson, A. J. 1956. Methods of chemical analysis for soil survey samples. New Zeal. DSIR Soil Bur. Bull. No. 12.

17. Muir, J. W. 1952. The determination of total phosphorus in soil, with particular reference to the control of interference by soluble silica. Analyst, 77:313-317.

18. Nockolds, S. R. 1933. Some theoretical aspects of con tamination in acid magmas. J. Geol. 41:461-589.

19. Peck, D. L. 1965. Solidification of Alae Lava Lake, Hawaii. Abstracts of Papers, Japan-US Coop. Sci. Programme, 3rd Gen. Meeting, Hakone, Japan, Oct. 28-26, 1965.

20. Plummer, J. K. 1915. Petrography of some North Carolina soils and its relation to fertilizer requirements. J. Agr. Res. 5:569-581.

21. Raeside, J. D. 1959. Stability of index minerals in soils with particular reference to quartz, zircon and garnet. J. Sediment. Petrol. 29:493-502.

22. Sherrell, C. G., and W.M.H. Saunders. 1966. An evaluation of methods for the determination of total phosphorus in soils. New Zeal. J. Agr. Res. 9:972-979.

23. Walker, T. W., and A. F. R. Adams. 1958. Studies on soil organic matter: 1. Influence of phosphorus content of parent materials on accumulations of carbon, nitrogen, sulphur and organic phosphorus in grassland soils. Soil Sci. 85:307-318.

24. Williams, H., F. J. Turner, and C. M. Gilbert. 1954. Petrography: An introduction to the study of rocks in thin sections. Freeman and Co., San Francisco.

25. Williams, J. D. H., J. K. Syers, and T. W. Walker. 1967. Fractionation of soil inorganic phosphate by a modification of Chang and Jackson's procedure. Soil Sci. Soc. Amer. Proc. $31: 736-739$. (this issue)

26. Wodzicki, A. 1959. Radioactive boulders in Hawks Crag breccia. New Zeal. J. Geol. Geophys. 2:385-393.

27. Wright, J. B., and J. F. Lovering. 1965. Electron-probe micro-analysis of the iron-titanium oxides in some New Zealand iron sands. Mineral. Mag. 35:604-621. 